\title{
Corynebacterium coyleae
}

National Cancer Institute

\section{Source}

National Cancer Institute. Corynebacterium coyleae. NCI Thesaurus. Code C122269.

A species of non-motile, catalase-positive, non-lipophilic, pleomorphic coryneform

bacteria in the family Corynebacteriaceae. C. coyleae is characterized by slow

fermentative acid production from glucose but no acid production from maltose and sucrose and a strongly positive CAMP reaction. The species produces acid from fructose, glucose, maltose, and sucrose and is urease-positive. 